\title{
FDI and FPI Determinants in Developing African Countries
}

\author{
Patricia Lindelwa Makoni \\ Department of Finance, Risk Management and Banking, University of South Africa (UNISA), South Africa \\ patricia.makoni@gmail.com
}

\begin{abstract}
We examine drivers of foreign direct investment (FDI) and foreign portfolio investment (FPI) in nine selected African economies, during the period 1980 to 2014, with particular interest in the role of financial market development. We set out to explore the drivers of FDI and FPI in selected African countries, respectively. We employ the dynamic GMM methodology to assess the motivators of inward foreign flows. The results show that FDI inflows are generally dependent on past inflows of FDI, low inflation, infrastructural development, and real GDP growth rate; while stock market capitalisation, commercial bank assets gauged against commercial and central bank assets as well as domestic credit to the private sector by banks intermediate for financial market development. On the other hand, we find that FPI inflows are attracted to foreign destinations due to previous FPI inflows, the real exchange rate, inflation rates and the presence of developed infrastructure. Further, developed financial markets, as proxied by stock market capitalisation, were found to significantly and positively influence inward FPI flows, while a closed financial account and low interest rate discouraged FPI. The significant contribution of this paper is that its findings empirically confirm FDI and FPI theory, as postulated in Dunning's eclectic paradigm insofar as the main "location" variables that enhance host country attractiveness are concerned, specifically in the African context. In light of these findings, we recommend that policy makers strengthen their domestic markets, complemented by appropriate regulations and institutions to attract foreign investment flows, while reducing their dependency on international aid and loans.
\end{abstract}

Keywords: Foreign direct investment (FDI), foreign portfolio investment (FPI), financial market development (FMD), GMM

\section{Introduction}

According to De Santis and Ehling(2007), international capital flows have attracted the interest of policymakers, central banks, international institutions, investors and academia. International capital flows can be classified as either foreign direct investment (FDI), foreign portfolio investment (FPI) or foreign debt (Kirabaeva \& Razin, 2013; Agbloyor, Abor, Adjasi \& Yawson, 2014). Asiedu (2006) lamented that foreign portfolio investment is unavailable to most African countries, and most of the countries on the continent cannot raise funds from international capital markets because their own domestic financial markets are not sufficiently developed. Makoni (2014) conceded that despite Africa being endowed with vast natural resource deposits, basic infrastructure and an abundant supply of low-cost human capital, there are still limited FDI inflows.

Figure 1: Composition of international capital flows to Africa (2000 - 2014)

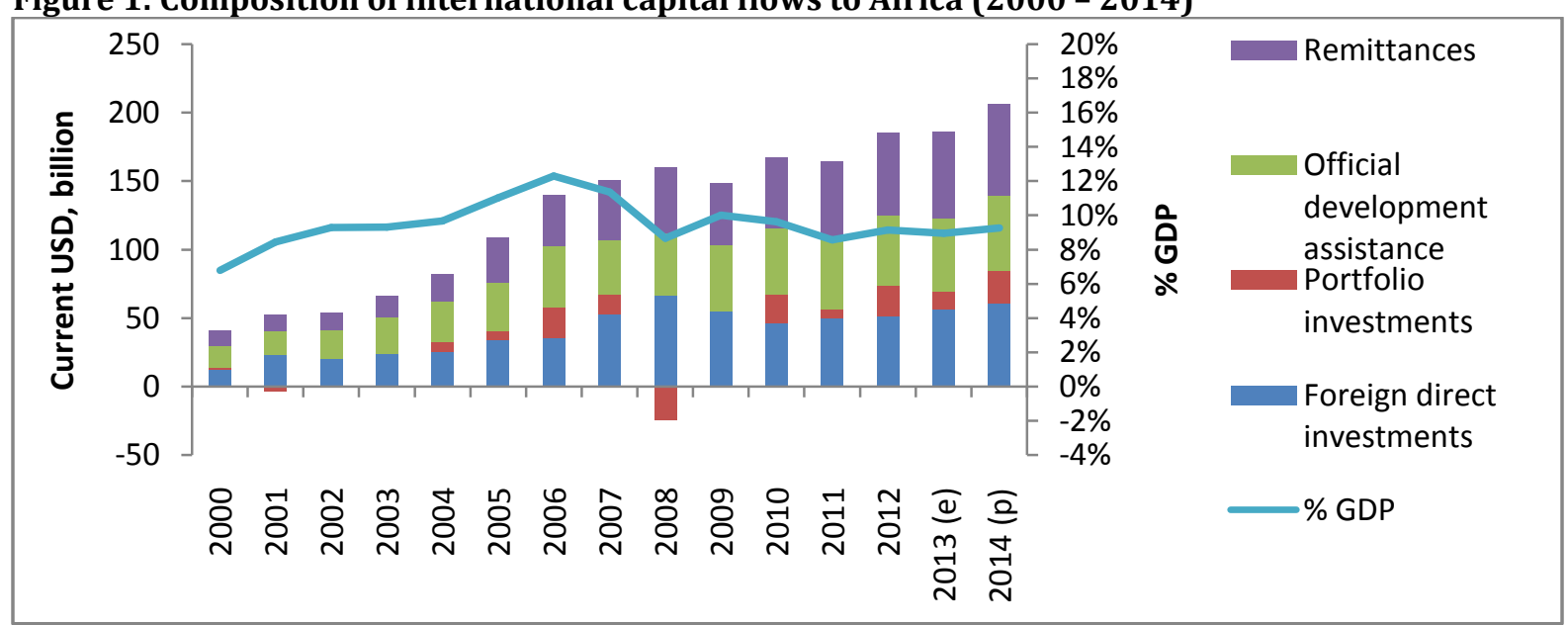

Source: African Development Bank (2015) 
In

, although FDI and FPI have both shown signs of recovery since the 2008 global financial crisis, these flows still remain significantly low. FDI inflows to Africa rose from US $\$ 46$ billion in 2008, to US $\$ 51.7$ billion in 2012, while FPI rebounded from a negative US $\$ 24.6$ billion position in 2008, to a positive US $\$ 22$ billion in 2012 (African Development Bank Economic Outlook Report, AfDB, 2015). Using country-level data for nine selected African countries for the period 1980 to 2014, this paper explores factors that give rise to inward FDI and FPI flows to selected African countries, looking specifically at the role played by financial market development, by employing the dynamic generalized method of moments (GMM). The remainder of this paper is as follows: Section 2 gives a detailed review of literature on the determinants of FDI and FPI, respectively. The data is presented in Section 3, while the methodology and empirical analyses are in Section 4. The paper ends with a brief discussion of the findings, conclusion and policy recommendations.

\section{Literature Review}

Foreign Direct Investment: FDI theory is rooted in the early work of Smith (1776) as cited in Smith (1937) and Ricardo (1817); andsuch theory was related to international specialisation of production. However, Smith's theory of absolute advantage did not explain how trade arose between countries where one country was not in the business of production, while Ricardo's (1817) FDI was based on the theory of comparative advantage. Ricardo's (1817) theory was also flawed because it was based on the assumptions of two countries, two products and perfect factor (labour and capital) mobility, but still did not justify international capital movements (Kindelberger, 1969). Other well-known scholars to theorise FDI include Mundell (1957), Vernon (1966), Casson (1979), Rugman (1980), Calvet (1981), Kojima and Ozawa (1984), and Grosse (1985). Although some of these researchers made a concerted effort to incorporate capital, location, industrial organisation, growth of the firm, market failure, foreign exchange parity, investment portfolio and product lifecycle theories into one whole theory to attempt to explain the motives and patterns of FDI, most credit is given to Dunning's eclectic paradigm (theory) of international production (Boddewyn, 1983).

Dunning's 1977 Eclectic Paradigm posits that FDI occurs under different scenarios of ownership, locational and internalisation advantages (OLI). According to Dunning (2000), in order for a firm to engage in foreign direct investment, a firm should possess net, firm-specific ownership advantages over other firms serving particular markets such as trademarks, patents, information and technology. Furthermore, FDI location is influenced by firm behaviour insofar as the motives of its location is concerned, that is, whether it is resourceseeking, market-seeking, efficiency-seeking or strategic asset seeking. However, the overarching decision is in fact taken on the basis of economic geography which considers country-level characteristics such as its natural resources endowment, availability of labour, local market size, infrastructure and government policy regarding these national resources (Popovici \& Calin, 2014). Lastly, it must be more profitable for the firm possessing these ownership advantages to use them for itself (internalisation), rather than to sell or lease them to foreign firms through licensing or management contracts (externalisation).

International empirical studies have highlighted human capital, degree of openness and inflation as being leading determinants of FDI. Al Nasser and Gomez (2009) tested the influence of financial market development and found a positive relationship between FDI and stock market development, as well as a significant and positive correlation between FDI inflows and credit offered by banks to the private sector. Later, Zheng (2009) found that inward FDI flows to China and India were influenced by domestic market growth, imports, cost of labour, and political risk. Similar to Zheng's (2009) survey were the findings of Leitao (2010) on Greece using data from 1998-2007, who concluded that trade openness; market size and labour costs were significant FDI determinants. Empirical evidence on Africa shows that the main FDI determinants are infrastructure, trade openness, natural resource endowment, low inflation and efficient legal systems (Anyanwu \& Erhijakpor, 2004; Asiedu, 2006; Bokpin, Mensah \& Asamoah, 2015).

Foreign Portfolio Investment: FPI theory, on the other hand, is premised on macroeconomic variables, namely interest rate differentials and exchange rate fluctuations. By extending the FDI eclectic paradigm, Dunning and Dilyard (1999) explained FPI using OLE (Ownership, Location and Externalisation). Their argument was that usually " $O$ " variables are already present, so the choice of outlet for FPI depends on "L" and "E" variables. The location "L" specific advantages were suggested to be the result of the host nation's 
political stability, level of financial market liberalisation and sophistication, as well as government macro and microeconomic policy. Finally, externalisation justifies the use of external markets rather than internal ones for the transfer of capital by playing a supporting role to ownership and location advantages.FPI provides opportunities for real economic growth, as well as potential social, economic and political development, including job creation, reduced cost of capital for domestic companies, forced compliance with transparency and corporate governance and capital market integration (Sawalha, Elian \& Suliman, 2016). According to Gumus, Duru and Gungor (2013), unlike FDI flows, FPI is affected by several macroeconomic factors, primarily through their interaction with the financial markets. Earlier empirical studies confirmed that FPI was influenced by interest rates, foreign exchange rates, inflation rates, economic growth, government consumption, country risk, political risk, transaction costs and rates of return (Ekeocha, Ekeocha, Malaolu \& Oduh, 2012; Sarno, Tsiakas \& Ulloa, 2015).Other studies show that investors seek destinations with sound institutions and good (corporate) governance principles, as well as developed local financial markets (Calvo, Leiderman\& Reinhart,1996; Fernandez-Arias, 1996; Chuhan, Claessens \& Mamingi, 1998).

The effects of financial intermediation and financial markets on economic growth is magnified through capital accumulation, i.e. the rate of investment, as developed financial markets result in higher mobilisation of savings amongst locals. According to Hearn, Piesse and Strange (2010), stock market development facilitates both FDI and FPI through the acquisition of shares in local firms, thereby supplementing low levels of domestic savings. Agbloyor, Abor, Adjasi \& Yawson(2011) add that for African studies, it is imperative to also examine the role of credit markets. Since the banking sector in Africa is much more developed than the equity markets, a significant amount of inward foreign investment is intermediated by banks rather than the stock markets. Hence, while stock markets provide equity finance for investment, the banking sector provides debt finance mobilised at low cost, thereby implying a complementary relationship between the two markets (Agbloyor et al., 2011). From the foregoing discussions, it has been ascertained that both FDI and FPI contribute to the economy of many developing countries. However, the various channels through which investors enter host countries is largely dependent on location-specific characteristics, which are often at the control of the host governments and policy-makers. With this in mind, we seek to identify and confirm the determinants of FDI and FPI and the specific role of the domestic financial markets in host countries in Africa. The next section examines the data set and variables of our paper.

\section{Methodology}

Data and variables: This study employed annual financial, economic and institutional quality data drawn from the World Bank's Development Indicators and Kuncic's (2014) databases. Table 1 below summarises the variables used in this study, and where they were also applied in similar studies.

Table 1: Indicators of FDI, FPI and FMD variables

\begin{tabular}{|c|c|c|}
\hline \multirow{2}{*}{\multicolumn{3}{|c|}{$\begin{array}{l}\text { Variable Indicator } \\
\text { FDI and FPI inflow variables }\end{array}$}} \\
\hline & & \\
\hline FDIGDP & Ratio of net FDI inflows to GDP & $\begin{array}{l}\text { Alfaro et al. (2004); Asiedu (2006); Otchere, } \\
\text { Soumaré \& Yourougou (2015) }\end{array}$ \\
\hline FPIGDP & Ratio of net FPI inflows to GDP & Agbloyor et al.(2014); Otchere et al.(2015) \\
\hline \multicolumn{3}{|c|}{ Financial market development variables } \\
\hline SMCAP & $\begin{array}{l}\text { Stock market capitalisation of listed } \\
\text { companies as } \% \text { of GDP }\end{array}$ & $\begin{array}{l}\text { Demirguc-Kunt \& Levine (1996); Chinn \& Ito } \\
\text { (2006); Agbloyor et al. (2013) }\end{array}$ \\
\hline SMTVT & $\begin{array}{l}\text { Stock market value traded (total value as \% } \\
\text { of GDP) }\end{array}$ & $\begin{array}{l}\text { Demirguc-Kunt \& Levine (1996); Chinn \& Ito } \\
\text { (2006); Soumaré \& Tchana (2015) }\end{array}$ \\
\hline PCRED & $\begin{array}{l}\text { Domestic credit to the private sector by } \\
\text { deposit banks as a share of GDP }\end{array}$ & $\begin{array}{l}\text { Demirguc-Kunt \& Levine (1996); Agbloyor et al. } \\
\text { (2014); Soumaré \& Tchana (2015) }\end{array}$ \\
\hline LIQLI & $\begin{array}{l}\text { Liquid liabilities of the financial system } \\
\text { (M3) divided by GDP }\end{array}$ & $\begin{array}{l}\text { Demirguc-Kunt \& Levine (1996); Alfaro et al. } \\
\text { (2004); Soumaré \& Tchana (2015) }\end{array}$ \\
\hline CCBA & $\begin{array}{l}\text { The ratio of commercial bank assets to } \\
\text { commercial bank and central bank assets }\end{array}$ & $\begin{array}{l}\text { Demirguc-Kunt \& Levine (1996); Alfaro et al. } \\
\text { (2004); Soumaré \& Tchana (2015) }\end{array}$ \\
\hline \multicolumn{3}{|c|}{ Economic and other control variables } \\
\hline
\end{tabular}




\begin{tabular}{|c|c|c|}
\hline RGDPG & Real GDP growth rate & $\begin{array}{l}\text { Ekeocha, Ekeocha, Victor \& Oduh (2012); Otchere } \\
\text { et al. (2015) }\end{array}$ \\
\hline REXCR & Real exchange rate & Ekeocha et al. (2012); Otchere et al. (2015) \\
\hline INFL & $\%$ change in GDP deflator & Asiedu (2006); Otchere et al. (2015) \\
\hline INFRAS & Log(telephone lines per 1,000 people) & $\begin{array}{l}\text { Asiedu (2006); Agbloyor et al. (2013); Otchere et } \\
\text { al. (2015) }\end{array}$ \\
\hline TRDOPN & Sum of imports and exports to GDP & $\begin{array}{l}\text { Allen \& Ndikumana (2000); Agbloyor et } \\
\text { al.(2013); Otchere et al. (2015) }\end{array}$ \\
\hline KAOPEN & $\begin{array}{l}\text { The extent of financial openness using the } \\
\text { capital account openness index (KAOPEN), } \\
\text { developed by Chinn and Ito }\end{array}$ & Chinn \& Ito $(2002 ; 2006 ; 2008)$ \\
\hline INTR & $\begin{array}{l}\text { The real interest rate as measured by the } \\
\text { lending interest rate, adjusted for inflation } \\
\text { by the GDP deflator }\end{array}$ & Agbloyor et al. (2013); Otchere et al. (2015) \\
\hline NATRES & Total natural resources rent scaled by GDP & $\begin{array}{l}\text { Yilmaz, Tag, Ozkan \& Degirmen (2014); Agbloyor, } \\
\text { Gyeke-Dako, Kuipo \& Abor (2016) }\end{array}$ \\
\hline INSTQ & $\begin{array}{l}\text { Institutional quality, measured by the } \\
\text { average of Kuncic's institutional quality } \\
\text { variables }\end{array}$ & Kuncic (2014) \\
\hline HUMCA & Gross primary school enrolment ratio & Soumaré\&Tchana (2015) \\
\hline
\end{tabular}

A panel data set covering nine African countries for the period 1980 to 2014 was used for our econometric analyses. This study was limited to a sample of nine countries with active stock markets, as well as the period of 35 years, due to data paucity. As such, we focused only on Botswana, Cote d'Ivoire, Egypt, Kenya, Mauritius, Morocco, Nigeria, South Africa, and Tunisia as the sample of African countries.

\section{Results}

As a preliminary to our econometrics, we ran descriptive statistics for the variables identified. Table 2summarises the descriptive statistics. The pooled results for the African economies in this study from 1980 2014indicate that the FDI inflows to Africa as a percentage of GDP were significantly low. The mean of net FDI inflows for the period under review was $2.54 \%$ of GDP, with a standard deviation of 12.5 . With regard to FPI inflows, the average was $0.85 \%$ of GDP, with a standard deviation of 5.7. The minimum FPI as a percentage of GDP was $-2.45 \%$, while the maximum was $80.48 \%$. In both cases, FDI and FPI disinvestment is deemed to have occurred in economies where the flow values were negative, thereby implying that outflows occurred during that period. The low FPI inflows could be attributed to the lowly developed financial markets in Africa, with most businesses depending on the banking sector rather than the stock markets as conduits for raising capital locally.

Table 2: Summary statistics for variables used in the pooled estimation $(1980$ - 2014)

\begin{tabular}{llllll}
\hline Variable & Obs & Mean & Std. dev. & Minimum & Maximum \\
\hline FDIGDP & 315 & 2.5384 & 12.4781 & -6.8976 & 220.0027 \\
CCBA & 315 & 84.9239 & 16.4528 & 30.6772 & 99.9982 \\
FPIGDP & 290 & 0.8532 & 5.6983 & -2.4517 & 80.4750 \\
HUMCA & 315 & 97.7552 & 14.0608 & 63.1297 & 119.8757 \\
INFL & 315 & 9.5592 & 11.9203 & -5.6657 & 113.0764 \\
INFRAS & 315 & 57.7868 & 67.5143 & 1.0267 & 315.0345 \\
INTR & 315 & 14.4184 & 4.8941 & 4.815 & 36.24 \\
PCRED & 315 & 42.5110 & 32.1195 & 6.6405 & 160.1249 \\
SMCAP & 290 & 36.9983 & 48.9544 & 1.8105 & 278.3918 \\
SMTVT & 290 & 8.1314 & 21.6165 & 0.0165 & 142.1928 \\
\hline
\end{tabular}




\begin{tabular}{llllll}
\multicolumn{5}{c}{$\begin{array}{l}\text { Journal of Economics and Behavioral Studies (ISSN: 2220-6140) } \\
\text { Vol. 9, No. 6, pp. 252-263, December 2017 }\end{array}$} \\
\hline \hline \multicolumn{6}{c}{} \\
\hline TRDOPN & 315 & 73.57416 & 25.9787 & 23.6089 & 137.1121 \\
INSTQ & 189 & 0.4992 & 0.1215 & 0.2543 & 0.7157 \\
NATRES & 315 & 9.2426 & 12.3902 & 0.0034 & 73.4978 \\
RGDPG & 315 & 3.9623 & 4.2602 & -13.1279 & 33.7358 \\
LIQLI & 315 & 49.8062 & 22.4802 & 12.8592 & 112.8303 \\
REXCR & 315 & 68.6415 & 147.9861 & 0.4050 & 733.0385 \\
KAOPEN & 306 & -0.5102 & 1.2994 & -1.8889 & 2.3897 \\
\hline
\end{tabular}

Using various dynamic panel data techniques, we set out to identify and examine the determinants of FDI and FPI, focusing mainly on the role of financial market development. The Hausman test was used to select the appropriate approach between fixed and random effects estimators in our panel data. Mundlak (1978) argued that the REM assumes exogeneity of all the regressors and the random individual effects. We failed to reject the null hypothesis, found no evidence that the random effects estimates are invalid, thereby making random effects more efficient than fixed effects for this study. We utilised dynamic Generalised Method of Moments (GMM) panel estimators to avoid spurious results arising from endogeneity problems, as well as to enhance robustness checks to our results by assuming that the past value of the explanatory variables is uncorrelated with the error term. The dynamic GMM panel data estimation method overcomes some of the shortcomings of cross-sectional estimation biases, such as the omitted variable errors, country-specific effects misspecification, endogeneity and the use of lagged dependent variables in the regression, which are generally encountered in panel data regressions.

The following dynamic generalised method of moments (GMM) models were specified:

$$
\begin{aligned}
& F_{i t}=\alpha_{0} F_{i t} I_{i t-1}+\alpha_{1} F D_{i t}+\alpha_{2} F P I_{i t}+\sum_{n=1}^{i} \beta X_{i t}+\varepsilon_{i t} \\
& F_{i t}=b_{0} F_{i t} I_{i t-1}+b_{1} F_{i t}+b_{2} F_{i t}+\sum_{n=1}^{i} \beta X_{i t}+\varepsilon_{i t}
\end{aligned}
$$

Where, $F D I_{i t}$ and $F P I_{i t}$ are the dependent variables measuring the inflows of foreign direct investment and foreign portfolio investment (US\$) as a percentage of GDP into country $i$ for time $t$, respectively. $F D I_{i t-1}$ and $F P I_{i t-1}$ represent the lag of FDI and FPI, respectively. $F M D_{i t}$ is proxied by different measures of financial market development. $\alpha_{0}$ and $b_{0}$ denote a constant term, while $\varepsilon_{i t}$ is a randomerror term. The error term $\varepsilon_{i t}$ breaks down into $\mu_{i}+v_{i t} . \mu_{i}$ represents the time invariant country-specific effect, while $v_{i t}$ represents the remainder of the disturbance in the estimated regressions. Vector $X_{i t}$ denotescontrol variables that explain the inflows of FDI and FPI to African countries, such as infrastructure, trade openness, human capital development, institutional quality, natural resources, inflation, interest rates, exchange rates, real GDP growth rates.

To overcome the challenge of endogeneity, we employed a GMM-based estimator, which allows for the efficient estimation in the presence of arbitrary heteroscedasticity, as it invokes the orthogonality conditions (Hansen, 2000). Specifically, we used the difference GMM estimator, also known as the Arellano-Bond linear dynamic estimator (Arellano \& Bond, 1991), suitable in instances where we have lagged endogenous variables as instruments and cross-section fixed effects. The Arellano-Bond estimation is re-estimated as the first difference of Equations 1 and 2, respectively, as follows:

$$
\Delta F D I_{i t}=\delta_{0}+\delta_{1} \Delta F D I_{i t-1}+\delta_{2} \Delta F P I_{i t}+\delta_{3} \Delta F M D_{i t}+\sum_{j=1}^{n} \delta_{j} \Delta X_{i t}+\Delta \varepsilon_{i t}
$$




$$
\Delta F P I_{i t}=\delta_{0}+\delta_{1} \Delta F P I_{i t-1}+\delta_{2} \Delta F D I_{i t}+\delta_{3} \Delta F M D_{i t}+\sum_{j=1}^{n} \delta_{j} \Delta X_{i t}+\Delta \varepsilon_{i t}
$$

(4)

Where, $\Delta$ represents the first difference operator, $\delta_{0}$ denotes a constant termand the other variables remain as described earlier.The first-difference transformation removes country-specific effects, which may be correlated with the exogenous variables, do not vary with time, hence can be easily removed through the first difference transformation. Failure to remove them, could lead to biases in the estimations. By instrumenting the first differenced lagged dependent variable in Equations 3 and 4, with its past levels (as done by the differenced GMM estimator), we are also able to control for any potential autocorrelation.

Discussion: The results from our GMM estimations for FDI are reported in Table 3. As expected, after accounting for endogeneity in the OLS estimation, we find that previous period FDI inflows, macro-economic stability proxied by low inflation rates, domestic credit to the private sector by banks and real GDP growth are positive and statistically significant in the GMM estimations. This confirms that a country that has previously been able to attract FDI will be able to maintain this position. This status quo will however be further advantaged by a stable economy with a low inflation rate and high growth prospects, in line with Asiedu (2006) and Otchere et al. (2015). Like the results of the study by Anyanwu and Erhijakpor (2004), we also find that infrastructural development gauged by fixed telephone lines per 1000 people, natural resource endowment, and real exchange rate are important for attracting FDI. On the downside, high interest rates and poor institutional quality were found to deter FDI inflows, similar to conclusions made by Asiedu (2006) and Anyanwu and Yameogo (2015).

Table 3: Dynamic panel data estimations: FDI

\begin{tabular}{|c|c|c|c|c|c|}
\hline & OLS & FE & $\mathbf{R E}$ & System GMM & Differenced GMM \\
\hline \multirow[t]{2}{*}{ L.FDIGDP } & 0.263 & 0.279 & 0.263 & $0.263^{* * *}$ & $0.317^{* * *}$ \\
\hline & $(1.33)$ & $(1.36)$ & $(1.42)$ & $(1.33)$ & $(4.08)$ \\
\hline \multirow[t]{2}{*}{ FPIGDP } & -0.0629 & -0.197 & -0.0629 & $-0.0629 * * *$ & $-0.196^{* *}$ \\
\hline & $(-0.55)$ & $(-1.52)$ & $(-0.59)$ & $(-0.55)$ & $(-11.79)$ \\
\hline \multirow[t]{2}{*}{ HUMCA } & -0.0338 & -0.143 & -0.0338 & -0.0338 & -0.144 \\
\hline & $(-0.92)$ & $(-1.71)$ & $(-0.99)$ & $(-0.92)$ & $(-0.76)$ \\
\hline \multirow[t]{2}{*}{ INFL } & 0.00629 & 0.0257 & 0.00629 & $0.00629 * *$ & $0.0254^{* * *}$ \\
\hline & $(0.33)$ & $(0.97)$ & $(0.41)$ & $(0.33)$ & $(16.52)$ \\
\hline \multirow[t]{2}{*}{ INFRAS } & 0.0584 & $0.0270^{*}$ & $0.0584^{*}$ & 0.0584 & 0.0250 \\
\hline & $(1.09)$ & $(2.65)$ & $(2.43)$ & $(1.09)$ & $(1.12)$ \\
\hline \multirow[t]{2}{*}{ INSTQ } & -11.27 & -19.43 & -11.27 & $-11.27^{* * *}$ & $-19.13^{* * *}$ \\
\hline & $(-0.99)$ & $(-0.92)$ & $(-0.73)$ & $(-0.99)$ & $(-5.21)$ \\
\hline \multirow[t]{2}{*}{ INTR } & -0.229 & -0.439 & -0.229 & $-0.229^{* *}$ & $-0.433^{* * *}$ \\
\hline & $(-1.14)$ & $(-1.30)$ & $(-0.79)$ & $(-1.14)$ & $(-3.81)$ \\
\hline \multirow[t]{2}{*}{ NATRES } & 0.0483 & 0.175 & 0.0483 & 0.0483 & 0.172 \\
\hline & $(1.85)$ & $(1.70)$ & $(0.90)$ & $(1.85)$ & $(0.44)$ \\
\hline \multirow[t]{2}{*}{ SMCAP } & 0.00884 & 0.0475 & 0.00884 & 0.00884 & 0.0472 \\
\hline & $(0.75)$ & $(0.92)$ & $(0.26)$ & $(0.75)$ & $(1.43)$ \\
\hline \multirow[t]{2}{*}{ SMTVT } & -0.0466 & -0.142 & -0.0466 & $-0.0466^{* *}$ & $-0.141^{* *}$ \\
\hline & $(-0.81)$ & $(-1.23)$ & $(-0.65)$ & $(-0.81)$ & $(-2.59)$ \\
\hline \multirow[t]{2}{*}{ CCBA } & -0.0182 & 0.0158 & -0.0182 & -0.0182 & 0.0154 \\
\hline & $(-0.57)$ & $(0.35)$ & $(-0.53)$ & $(-0.57)$ & $(0.11)$ \\
\hline \multirow[t]{2}{*}{ LIQLI } & -0.0493 & -0.0461 & -0.0493 & -0.0493 & -0.0459 \\
\hline & $(-0.94)$ & $(-0.59)$ & $(-0.93)$ & $(-0.94)$ & $(-0.55)$ \\
\hline \multirow[t]{2}{*}{ PCRED } & 0.0155 & 0.222 & 0.0155 & $0.0155^{* *}$ & $0.221^{* * *}$ \\
\hline & $(0.55)$ & $(1.39)$ & $(0.49)$ & $(0.55)$ & $(52.62)$ \\
\hline
\end{tabular}




\begin{tabular}{llllll} 
& \multicolumn{5}{c}{$\begin{array}{c}\text { Journal of Economics and Behavioral Studies (ISSN: 2220-6140) } \\
\text { Vol. 9, No. 6, pp. 252-263, December 2017 }\end{array}$} \\
\hline \hline \multirow{2}{*}{ REXCR } & 0.000798 & 0.0129 & 0.000798 & 0.000798 & 0.0127 \\
& $(0.48)$ & $(1.33)$ & $(0.23)$ & $(0.48)$ & $(0.79)$ \\
RGDPG & 0.0960 & 0.0939 & 0.0960 & $0.0960^{* *}$ & $0.0925^{* *}$ \\
& $(1.21)$ & $(1.74)$ & $(1.35)$ & $(1.21)$ & $(3.21)$ \\
TRDOPN & 0.0246 & -0.0473 & 0.0246 & 0.0246 & -0.0493 \\
& $(1.40)$ & $(-0.93)$ & $(1.31)$ & $(1.40)$ & $(-0.38)$ \\
\multirow{2}{*}{ cons } & 11.46 & 21.73 & 11.46 & 11.46 & 11.46 \\
& $0.95)$ & $(1.40)$ & $(0.91)$ & $(0.95)$ & $(0.95)$ \\
N & 305 & 305 & 305 & 305 & 305 \\
\hline
\end{tabular}

t statistics in parentheses ${ }^{*} \mathrm{p}<0.05^{* *} \mathrm{p}<0.01^{* * *} \mathrm{p}<0.001$

NB: diagnostic test results are reported in Table 4 below.

Table 4: FDI diagnostic tests

\begin{tabular}{llllll}
\hline & OLS & $\begin{array}{l}\text { FIXED } \\
\text { EFFECTS }\end{array}$ & $\begin{array}{l}\text { RANDOM } \\
\text { EFFECTS }\end{array}$ & $\begin{array}{l}\text { 2 STEP } \\
\text { GMM }\end{array}$ & $\begin{array}{l}\text { SYSTEM } \\
\text { GMMERENCED }\end{array}$ \\
\hline Observations & 306 & 306 & 306 & 297 & 297 \\
Groups & 9 & 9 & 9 & 9 & 9 \\
F-stats/Wald chi2 & 3.73 & & & 63.86 & 705.34 \\
Prob>F/Prob>Wald & & & & & 0 \\
chi2 & 0 & & & 0 & \\
Hausman Test & & 14.59 & 14.59 & & \\
Prob>chi2 & & 0.5550 & 0.5550 & & \\
R-SQUARED & & & & & \\
Within & & 0.1037 & 0.0734 & & \\
Between & 0.0677 & 0.6406 & & \\
Overall & 0.0825 & 0.0206 & 0.0835 & & -0.06 \\
rho & 0.2514 & - & & 0.948 \\
Arellano-Bond AR(1) & & & & -0.57 & 0.04 \\
Prob>z & & & 0.57 & 0.964 \\
Arellano-Bond AR(2) & & & & -2.10 & 1.09 \\
Prob>z & & & 0.035 & 0.454 \\
Sargan test of overid & & & & 1.04 & 0.5 \\
Prob>chi2 & & & 0.594 & 0.862 \\
Hansen test of overid & & & & 0.6 & 8 \\
Prob>chi2 & & & 0.741 & \\
Instruments & & & 8 & \\
\hline
\end{tabular}

An unexpected result for us was the positive impact that domestic credit to the private sector by banks (PCRED) has on inward FDI flows to our sampled African economies. PCRED measures financial intermediary activity and the efficiency of channelling savings to investors, and is considered to be a common investment vehicle in countries where the stock market is under-developed (Ghartey, 2015). As Anyanwu (2012) pointed out, a high level of credit to the private sector indicates an abundance of domestic capital, in which case, FDI would not be necessary. It was indicated earlier on in this paper that African receives limited inflows of FDI and even less of FPI, thus our finding could in fact imply that domestic savings in these countries are minimal, thereby necessitating FDI. Stock market capitalisation and the ratio of commercial bank assets as a share of the sum of commercial bank and central bank assets (CCBA), also feature as drivers in harnessing FDI inflows by playing an efficient intermediary role of allocating excess funds' in the economy to deficient but productive sectors. Soumaré and Tchana (2015) examined the relationship between FDI and FMD in 29 emerging market economies from 1994 - 2006, and found that FDI and stock market capitalisation have a simultaneous and positive impact on each other (bi-directional causality), while the results for PCRED, CCBA and LIQLI were ambiguous and inconclusive. 
On the determinants of FPI, Table 5 indicates that the lag of FPI was positive and highly significant, thereby supporting the proposition that prospective investors examine past trends of FPI prior to making financial commitments in foreign countries. Infrastructural development, institutional quality and stock market capitalisation were also found to positively influence inflows of FPI. These findings are in line with the studies by Daude and Fratzscher (2008) as well as Aggarwal, Klapper and Wyosocki (2005) who earlier found that inward foreign investments were highest in countries strong investor protection, legal framework and accounting standards. It has been argued that infrastructure is key for information dissemination; as are institutions and regulations regarding repatriation of investment income, as well the mere existence a stock market to trade shares the domestic share markets. Foreign direct investment (FDI) and a closed capital account were determined to shun FPI.

Table 5: Dynamic panel data estimations: FPI

\begin{tabular}{|c|c|c|c|c|c|}
\hline & OLS & RE & FE & System GMM & Differenced GMM \\
\hline \multirow[t]{2}{*}{ L.FPIGDP } & $0.431^{*}$ & $0.400^{* * *}$ & $0.431^{* * *}$ & $0.450 * * *$ & $0.444^{* * *}$ \\
\hline & $(2.43)$ & $(10.37)$ & $(10.68)$ & $(6.03)$ & $(7.41)$ \\
\hline \multirow[t]{2}{*}{ FDIGDP } & -0.00402 & -0.0123 & -0.00402 & -0.00480 & -0.0123 \\
\hline & $(-0.21)$ & $(-1.27)$ & $(-0.48)$ & $(-0.26)$ & $(-0.72)$ \\
\hline \multirow[t]{2}{*}{ KAOPEN } & -0.0433 & -0.665 & -0.0433 & -0.0268 & -0.657 \\
\hline & $(-0.40)$ & $(-1.06)$ & $(-0.16)$ & $(-0.61)$ & $(-1.45)$ \\
\hline \multirow[t]{2}{*}{ INFL } & 0.00430 & 0.00165 & 0.00430 & 0.00256 & 0.00172 \\
\hline & $(0.54)$ & $(0.31)$ & $(0.52)$ & $(0.63)$ & $(0.04)$ \\
\hline \multirow[t]{2}{*}{ INFRAS } & 0.0215 & 0.0273 & $0.0215^{*}$ & $0.00344^{* * *}$ & $0.0260^{* * *}$ \\
\hline & $(1.08)$ & $(1.68)$ & $(2.18)$ & $(1.44)$ & $(3.61)$ \\
\hline \multirow[t]{2}{*}{ INSTQ } & 2.715 & 5.392 & 2.715 & 0.268 & 5.262 \\
\hline & $(1.16)$ & $(1.23)$ & $(1.32)$ & $(0.69)$ & $(1.60)$ \\
\hline \multirow[t]{2}{*}{ INTR } & -0.120 & -0.226 & -0.120 & $-0.0149 * * *$ & $-0.223^{* * *}$ \\
\hline & $(-1.01)$ & $(-1.02)$ & $(-0.76)$ & $(-1.30)$ & $(-8.02)$ \\
\hline \multirow[t]{2}{*}{ SMCAP } & 0.0201 & 0.0440 & 0.0201 & $0.00593^{* * *}$ & $0.0435^{* * *}$ \\
\hline & $(1.48)$ & $(1.11)$ & $(0.93)$ & $(1.83)$ & $(3.39)$ \\
\hline \multirow[t]{2}{*}{ SMTVT } & -0.0396 & -0.0703 & -0.0396 & $-0.00867^{* * *}$ & $-0.0688^{* * *}$ \\
\hline & $(-1.12)$ & $(-1.26)$ & $(-1.03)$ & $(-1.34)$ & $(-4.15)$ \\
\hline \multirow[t]{2}{*}{ CCBA } & -0.0439 & -0.0380 & -0.0439 & $-0.00687^{* * *}$ & $-0.0368^{* * *}$ \\
\hline & $(-1.14)$ & $(-1.55)$ & $(-1.45)$ & $(-1.59)$ & $(-11.14)$ \\
\hline \multirow[t]{2}{*}{ LIQLI } & -0.0123 & -0.0159 & -0.0123 & -0.00462 & -0.0161 \\
\hline & $(-1.42)$ & $(-0.81)$ & $(-1.53)$ & $(-1.72)$ & $(-0.55)$ \\
\hline \multirow[t]{2}{*}{ PCRED } & -0.00500 & 0.0189 & -0.00500 & 0.000127 & 0.0188 \\
\hline & $(-0.65)$ & $(1.01)$ & $(-0.43)$ & $(0.04)$ & $(0.28)$ \\
\hline \multirow[t]{2}{*}{ REXCR } & 0.00155 & 0.00579 & 0.00155 & -0.000161 & 0.00574 \\
\hline & $(0.85)$ & $(1.23)$ & $(0.91)$ & $(-0.59)$ & $(0.92)$ \\
\hline \multirow[t]{2}{*}{ RGDPG } & 0.0224 & 0.0108 & 0.0224 & 0.00825 & 0.0101 \\
\hline & $(0.95)$ & $(0.48)$ & $(1.17)$ & $(0.90)$ & $(0.58)$ \\
\hline \multirow[t]{2}{*}{ _cons } & 3.541 & 0.997 & 3.541 & 0.737 & 0.821 \\
\hline & (1.14) & $(0.50)$ & (1.03) & $(1.74)$ & (1.87) \\
\hline $\mathrm{N}$ & 306 & 306 & 306 & 306 & 306 \\
\hline \multicolumn{6}{|c|}{ t statistics in parentheses $* p<0.05$} \\
\hline
\end{tabular}

NB: diagnostic test results are captured in Table 6 below. 
We conclude that our findings are similar to those of De Santis and Ehling (2007) who stated that the most important factor determining FDI and FPI transactions is the stock market. The stock market helps explain FDI because it produces signals that are relevant for firm investors. Foreign stock markets and home stock markets determine FPI because they measure the investment opportunity set and wealth effects. Portes and Rey (2005) also found that stock market capitalisation is a key driver of equity flows.

Table 6: FPI diagnostic tests

\begin{tabular}{llllll}
\hline & OLS & FE & FE & $\begin{array}{l}\text { 2 STEP SYSTEM } \\
\text { GMM }\end{array}$ & $\begin{array}{l}\text { DIFFERENCED } \\
\text { GMM }\end{array}$ \\
\hline Observations & 306 & 306 & 306 & 297 & 297 \\
Groups & 9 & 9 & 9 & 9 & 9 \\
F-stats/Wald chi2 & 22.12 & & & 77.61 & 765.48 \\
Prob>F/Prob>Wald & & & & & 0 \\
chi2 & 0 & & & 0 & \\
Hausman Test & & 11.80 & 11.80 & & \\
Prob>chi2 & & 0.6224 & 0.6224 & & \\
R-SQUARED & & & & & \\
Within & & 0.2830 & 0.2653 & & \\
Between & 0.3807 & 0.8541 & & \\
Overall & 0.3084 & 0.2383 & 0.3048 & & -0.01 \\
rho & 0.1746 & - & & -1.02 & \\
Arellano-Bond AR(1) & & & & 0.309 & -0.01 \\
Prob>z & & & -0.99 & 0.95 \\
Arellano-Bond AR(2) & & & & 0.320 & 0.01 \\
Prob>z & & & & 3.05 & 0.751 \\
Sargan test of overid & & & & 0.962 & 0.01 \\
Prob>chi2 & & & & 0.40 & 0.979 \\
Hansen test of overid & & & & 0.99 & 8 \\
Prob>chi2 & & & & & \\
Instruments & & & & & \\
\hline
\end{tabular}

\section{Conclusion and Recommendations}

The aim of this paper was to identify key drivers of FDI and FPI inflows, respectively, to selected African countries. The study confirmed that the previous period's FDI inflows, low inflation, infrastructural development, and real GDP growth rate made countries attractive to foreign investors. Individual financial market variables responsible for the driving inward FDI flows were stock market capitalisation, commercial bank assets gauged against commercial and central bank assets as well as domestic credit to the private sector by banks. On the other hand, FDI was deterred by poor institutional quality and high interest rates. FPI inflows to the selected African countries were enhanced by previous FPI inflows, the real exchange rate, inflation rates and the presence of developed infrastructure. These findings were in line with FPI theory which is premised upon macroeconomic variables, namely interest rate differentials and exchange rate fluctuations, as well as the work of Gumus et al. (2013), who reiterated that FPI is affected by several macroeconomic factors, primarily through their interaction with the financial markets. Developed financial markets as proxied by stock market capitalisation were found to significantly and positive influence inward FPI flows while a closed financial account and low interest rate discouraged FPI. These findings were in line with theory and earlier empirical studies. Insofar as FDI and FPI theory go - this study confirmed the main "location" variables which enhance host country attractiveness as stated in Dunning's eclectic paradigm.

Law and Habibullah (2009) affirmed that well-functioning financial markets and financial institutions should be a policy priority for governments. It is thus recommended that African governments should formulate investment policies which will diversify and develop their other economic sectors such as manufacturing, 
agriculture and even financial services, which in the long-run contribute to macro-economic policy goals, while moving away from their dependence on natural resources such as the mining sector alone. Also, there is a growing need to enhance the attraction of domestic financial markets by improving instrument offerings so as to attract increased levels of FPI inflows. Despite having conducted a comprehensive study examining the determinants of FDI and FPI, there is scope for further research. Proposals include identifying the long-run relationships and directions of causality between FDI, FPI and FMD to cover other facets of the FDI-FPI-FMD nexus. With all previous studies having examined FMD using individual market variables, there is an opportunity to develop a composite index to reflect the overall level of financial market development; of which findings can be compared to other studies.

\section{References}

African Development Bank (AfDB) (2015). African economic outlook 2014 (Report). African Development Bank.

Agbloyor, E. K., Abor, J. Y., Adjasi, C. K. D. \& Yawson, A. (2014). Private capital flows and economic growth in Africa: The role of domestic financial markets. Journal of International Financial Markets, Institutions and Money, 30, 137-152. doi: http://dx.doi.org/10.1016/j.intfin.2014.02.003

Agbloyor, E. K., Abor, J., Adjasi, C. K. D. \& Yawson, A. (2013). Exploring the causality links between financial markets and foreign direct investment in Africa. Research in International Business and Finance, 28, 118-134. doi: http://dx.doi.org/10.1016/j.ribaf.2012.11.001

Agbloyor, E. K., Abor, J., Adjasi, C. K. D. \& Yawson, A. (2011). Financial Markets and Cross Border Mergers and Acquisitions in Africa. Available at SSRN 1914478. doi: http://dx.doi.org/10.2139/ssrn.1914478

Agbloyor, E. K., Gyeke-Dako, A., Kuipo, R. \& Abor, J. Y. (2016). Foreign direct investment and economic growth in SSA: The role of institutions. Thunderbird International Business Review. Available online only. doi: http://dx.doi.org/10.1002/tie.21791

Aggarwal, R., Klapper, L. \& Wysocki, P. D. (2005). Portfolio preferences of foreign institutional investors. Journal of Banking \& Finance, 29(12), 2919-2946. doi: http://dx.doi.org/10.1016/j.jbankfin.2004.09.008,

Ahmed, A. D. (2013). Effects of financial liberalization on financial market development and economic performance of the SSA region: An empirical assessment. Economic Modeling, 30, 261-273. doi: http://dx.doi.org/10.1016/j.econmod.2012.09.019

Al Nasser, 0. \& Gomez, X. G. (2009). Do well-functioning financial systems affect the FDI flows to Latin America. International Research Journal of Finance and Economics, 29, 60-75.

Alfaro, L., Chanda, A., Kalemli-Ozcan, S. \& Sayek, S. (2004). FDI and economic growth: The role of local financial markets. Journal of International Economics, 64(1), 89-112.

Aliber, R. Z. (1970). A theory of direct foreign investment. The International Corporation, 2, 17-34.

Anyanwu, J. C. \& Yameogo, N. D. (2015). What drives foreign direct investments into West Africa? An empirical investigation. African Development Review, 27(3), 199-215. doi: http://dx.doi.org/10.1111/1467-8268.12141.

Anyanwu, J. C. \& Erhijakpor, A. E. (2004). Trends and determinants of foreign direct investment in Africa. West African Journal of Monetary and Economic Integration, 2, 21-44.

Anyanwu, J. C. (2012). Why does foreign direct investment go where it goes? New evidence from African countries. Annals of Economics and Finance, 13(2), 425-462.

Arellano, M. \& Bond, S. (1991). Some tests of specification for panel data: Monte Carlo evidence and an application to employment equations. The Review of Economic Studies, 58(2), 277-297. doi: http://dx.doi.org/10.2307/2297968.

Asiedu, E. (2006). Foreign direct investment in Africa: The role of natural resources, market size, government policy, institutions and political instability. The World Economy, 29(1), 63-77. doi: http://dx.doi.org/10.1111/j.1467-9701.2006.00758.x

Beck, T., Demirgüç-Kunt, A. \& Levine, R. (2000). A new database on the structure and development of the financial sector. The World Bank Economic Review, 14(3), 597-605. doi: http://dx.doi.org/10.1093/wber/14.3.597

Boddewyn, J. J. (1983). Foreign direct divestment theory: Is it the reverse of FDI theory? Review of World Economics, 119(2), 345-355. 
Bokpin, G. A., Mensah, L. \& Asamoah, M. E. (2015). Foreign direct investment and natural resources in Africa. Journal of Economic Studies, 42(4), 608-621. doi: http://dx.doi.org/10.1108/JES-01-20140023.

Calvet, A. L. (1981). A synthesis of foreign direct investment theories and theories of the multinational firm. Journal of International Business Studies, 12(1), 43-59.

Calvo, G. A., Leiderman, L.\& Reinhart, C. M. (1996). Inflows of capital to developing countries in the 1990s. The Journal of Economic Perspectives, 10(2), 123-139.

Casson, M. (1979). Alternatives to the multinational enterprise. London: MacMillan

Chinn, M. D.\& Ito, H. (2008). A new measure of financial openness. Journal of Comparative Policy Analysis: Research and Practice, 10(3), 309-322. doi: http://dx.doi.org/10.1080/13876980802231123

Chinn, M. D.\& Ito, H. (2006). What Matters for Financial Development? Capital Controls, Institutions, and Interactions. Journal of Development Economics, 81(1), 163-192. doi:10.1016/j.jdeveco.2005.05.010

Chinn, M. D. \& Ito, H. (2002). Capital Account Liberalization, Institutions and Financial Development: Cross Country Evidence, NBER Working Paper No. 8967. Available from http://econpapers.repec.org/RePEc:nbr:nberwo:8967

Chuhan, P., Claessens, S. \& Mamingi, N. (1998). Equity and bond flows to Latin America and Asia: The role of global and country factors. Journal of Development Economics, 55(2), 439-463. doi: http://dx.doi.org/10.1016/S0304-3878(98)00044-3

Daude, C. \& Fratzscher, M. (2008). The pecking order of cross-border investment. Journal of International Economics, 74(1), 94-119. doi: http://dx.doi.org/10.1016/j.jinteco.2007.05.010.

De Santis, R. A. \& Ehling, P. (2007). Do international portfolio investors follow firms' foreign investment decisions? ECB Working Paper No. 815. Available at SSRN: http://ssrn.com/abstract=1015266

Demirgüç-Kunt, A. \& Levine, R. (1996). Stock market development and financial intermediaries: Stylized facts. The World Bank Economic Review, 10(2), 291-321.

Demirgüç-Kunt, A.\& Detragiache, E. (1998). Financial liberalization and financial fragility. (IMF Working Paper No. 98/83). IMF.

Dunning, J. H. \& Dilyard, J. R. (1999). Towards a general paradigm of foreign direct and foreign portfolio investment. Editorial Statement, 8(1), 1.

Dunning, J. H. (2000). The eclectic paradigm as an envelope for economic and business theories of MNE activity. International Business Review, 9(2), 163-190.

Ekeocha, P. C., Ekeocha, C. S., Victor, M. \& Oduh, M. O. (2012). Modeling the long run determinants of foreign portfolio investment in Nigeria. Journal of Economics and Sustainable Development, 3(8), 194-205.

Eryigit, S. B., Eryigit, K. Y. \& Dülgeroglu, E. (2015). Local financial development and capital accumulations: Evidence from Turkey. Panoeconomicus, 62(3), 339.

Fernandez-Arias, E. (1996). The new wave of private capital inflows: Push or pull? Journal of Development Economics, 48(2), 389-418. doi: http://dx.doi.org/10.1016/0304-3878(95)00041-0.

Forssbaeck, J. \& Oxelheim, L. (2011). FDI and the role of financial market quality. In Ravi Ramamurti, Niron Hashai (ed.) The Future of Foreign Direct Investment and the Multinational Enterprise (Research in Global Strategic Management, Volume 15) Emerald Group Publishing Limited, (pp.85 - 109). http://dx.doi.org/10.1108/S1064-4857(2011)0000015010.

Grosse, R. (1985). An imperfect competition theory of the MNE. Journal of International Business Studies, 16(1), 57-80.

Gumus, G. K., Duru, A. \& Gungor, B. (2013). The relationship between foreign portfolio investment and macroeconomic variables. European Scientific Journal,9(34), online. Available from http://search.proquest.com/docview/1524879745?accountid=14648.

Hansen, B. E. (2000). Econometrics. 1st Ed. Madison, WI.

Hearn, B., Piesse, J. \& Strange, R. (2010). Market liquidity and stock size premia in emerging financial markets: The implications for foreign investment. International Business Review, 19(5), 489-501. doi: http://dx.doi.org/10.1016/j.ibusrev.2009.02.009.

Kindelberger, C. P. (1969). American business abroad: Six lectures on direct investment.The International Executive, 11(2), 11-12.New Haven, CT: Yale UP.

King, R. G. \& Levine, R. (1993). Finance and growth: Schumpeter might be right. The Quarterly Journal of Economics, 108(3), 717-737. doi: http://dx.doi.org/10.2307/2118406. 
Kirabaeva, K. \& Razin, A. (2013). Composition of international capital flows. In Gerard Caprio (Ed.), The evidence and impact of financial globalization (3, 105-119). Oxford: Elsevier Inc. doi: http://dx.doi.org/10.1016/B978-0-12-397874-5.00019-1.

Knickerbocker, F. T. (1973). Oligopolistic reaction and multinational enterprise. The International Executive, 15(2), 7-9. doi: http://dx.doi.org/10.1002/tie.5060150205.

Kojima, K. \& Ozawa, T. (1984). Micro- and macro-economic models of direct foreign investment: Toward a synthesis. Hitotsubashi Journal of Economics, 25(1), 1-20.

Kuncic, A. (2014). Institutional Quality Dataset. Journal of Institutional Economics, 10(1), 135-161.

Law, S. H. \& Habibullah, M. S. (2009). The determinants of financial development: Institutions, openness and financial liberalisation. South African Journal of Economics, 77(1), 45-58.

Leitão, N. C. (2010). Localization factors and inward foreign direct investment in Greece. Theoretical and Applied Economics, 2, 17-26.

Makoni, P. L. (2014). Factors influencing the attraction of foreign direct investment and foreign portfolio investment into African economies. Corporate Ownership \& Control, 11(4), 203-213.

Mundell, R. A. (1957). International trade and factor mobility. The American Economic Review, 47(3), 321-335.

Mundlak, Y. (1978). On the pooling of time series and cross section data. Econometrica, 46(1), 69-85. doi: http:dx.doi.org/10.2307/1913646.

Otchere, I., Soumaré, I. \& Yourougou, P. (2015). FDI and financial market development in Africa. The World Economy, online, 1-28. doi:10.1111/twec.12277

Popovici, O. C. \& Călin, A. C. (2014). FDI theories. A location-based approach. Romanian Economic Journal, 17(53), 3-24.

Ricardo, D. (1817). On foreign trade. Principles of Political Economy and Taxation. London.

Rugman, A. M. (1980). Internalization as a general theory of foreign direct investment: A re-appraisal of the literature. Review of World Economics, 116(2), 365-379.

Sarno, L., Tsiakas, I. \& Ulloa, B. (2016). What drives international portfolio flows? Journal of International Money and Finance, 60, 53-72. doi: http://dx.doi.org/10.1016/j.jimonfin.2015.03.006

Sawalha, N. N., Elian, M. I. \& Suliman, A. H. (2016). Foreign capital inflows and economic growth in developed and emerging economies: A comparative analysis. The Journal of Developing Areas, 50(1), 237-256.

Smith, A. (1937). The wealth of nations [1776]

Soumaré, I. \& Tchana, F. T. (2015). Causality between FDI and financial market development: Evidence from emerging markets. The World Bank Economic Review, Online, lhv015. doi: http://dx.doi.org/10.1093/wber/lhv015.

Vernon, R. (1966). International investment and international trade in the product cycle. The Quarterly Journal of Economics, 80(2), 190-207.

World Bank Group. (2015). World development indicators (WDI) 2015. World Bank Publications.

Zakaria, Z. (2007). The causality relationship between financial development and foreign direct investment. Jurnal Kemanusiaan, 10, 1-23.

Zheng, P. (2009). A comparison of FDI determinants in China and India. Thunderbird International Business Review, 51(3), 263-279. doi: http://dx.doi.org/10.1002/tie.20264. 